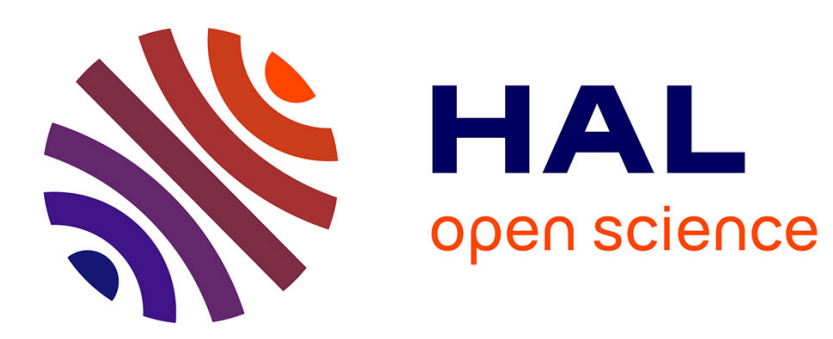

\title{
The auditory demonstrative in Khaling
}

Guillaume Jacques, Aimée Lahaussois

\section{To cite this version:}

Guillaume Jacques, Aimée Lahaussois. The auditory demonstrative in Khaling. Studies in Language, 2014, 38 (2), pp.335-346. 10.1075/sl.38.2.05jac . halshs-01244878

\section{HAL Id: halshs-01244878 \\ https://shs.hal.science/halshs-01244878}

Submitted on 16 Dec 2015

HAL is a multi-disciplinary open access archive for the deposit and dissemination of scientific research documents, whether they are published or not. The documents may come from teaching and research institutions in France or abroad, or from public or private research centers.
L'archive ouverte pluridisciplinaire HAL, est destinée au dépôt et à la diffusion de documents scientifiques de niveau recherche, publiés ou non, émanant des établissements d'enseignement et de recherche français ou étrangers, des laboratoires publics ou privés. 


\title{
The auditory demonstrative in Khaling*
}

\author{
Guillaume Jacques \\ Aimée Lahaussois
}

December 16, 2015

\begin{abstract}
This paper shows the existence of an auditory demonstrative in Khaling. The use of the demonstrative is illustrated via examples taken from narrative discourse. It is described here within the context of the spatial demonstrative system, in order to demonstrate how it is specifically used to highlight that perception of the referent is attained using the sense of audition, regardless of the visibility of the object in question. Khaling appears to be unique in having a true auditory demonstrative and it is hoped that this description will prompt field linguists to refine the description of the contrasts found within the demonstrative systems of languages around the world.

Keywords: spatial deixis; cross-modal perception; audition; demonstratives; Kiranti languages; Khaling;
\end{abstract}

\section{Introduction}

The existence of perceptual contrasts on demonstratives has been amply attested in many language families. The cross-linguistically most common such phenomenon, and the first to have been described, is the distinction between demonstratives contrasting visible and non-visible referents. For such languages, one set of demonstratives is used for referents within the field of vision of speech act participants, while the other set is used for referents outside the field of vision. In yet other languages, the feature of vision may be irrelevant in using a demonstrative (although of course

\footnotetext{
"We wish to thank Thank to Sasha Aikhenvald, Balthasar Bickel, Isabelle Bril, Alexandre François, Nathan Hill, Lukas Neukom, N.A. Walker, and the anonymous reviewers for useful comments. We also wish express our gratitude to our Khaling consultants, especially Dhan Bahadur Rai, Dhan Maya Rai and Yadav Kumar Rai. The transcription of Khaling strictly follows the IPA; in particular, the symbol $j$ is used to represent the palatal glide, not the voiced coronal affricate as in most works on Kiranti languages. This research was funded by the HimalCo project (ANR-12-CORP-0006) and is related to the research strand LR-4.11 "Automatic Paradigm Generation and Language Description" of the Labex EFL (funded by the ANR/CGI).
} 
visibility of the referent is the most common situation in which demonstratives are used, considering their deictic nature): these demonstratives might be called 'standard', and be applicable to abstract concepts, among other things. Among languages with a visibility contrast, a proximal/distal contrast, encoding the relative distance of the referent from the speaker, might also be present, and in some cases inseparable from the visibility feature. This is the case of Dyirbal (Dixon 1972), which has a three-way distinction between bala- 'referent is visible and not near speaker'; yala'referent is visible and near speaker'; and gala- 'referent is not visible (but may be audible or remembered from the past).'

Languages where the visibility contrast is independent from, and can be combined with, the proximal / distal distinction are also attested. The bestknown case is that of Kwak'wala (Boas 1911: 527-531), but such systems are also attested elsewhere (Aikhenvald 2004: 130 and Aikhenvald and Dixon 2014).

Demonstratives which grammaticalize perception via senses other than vision appear to be rare; none are mentioned in Diessel (1999)'s survey of demonstrative systems. Such systems nonetheless exist, although they generally consist of distinguishing visual perception from perception via other senses (in other words audition, taste, touch, smell, etc). In previously documented cases, terms like 'auditory' (Oswalt 1986: 37, ft), 'auditive' (Neukom 2001: 42-44), 'audible' (Dixon 1972) are used to refer to nonvisual perception, not exclusively audition.

Yet systems where audition is the exclusive relevant perceptual channel for demonstrative selection also exist. This is the case of Khaling, a Kiranti language of Eastern Nepal, which has a genuine auditory demonstrative: it is used, for both visible and out-of-sight referents, to indicate that the deictically dominant perceptual channel is auditory. It cannot be used for perception via other senses such as smell or touch.

This paper is divided into four sections. First, we present background information on Khaling, including some data on nominalization, which is relevant to understanding how the demonstratives are used. Second, we describe the use of the auditory demonstrative in natural discourse. Third, we provide data on the rest of the demonstrative system and spatial adverbs, and show that the proximal / distal contrast is not correlated with any visual / non-visual distinction, although native speaker intuition sometimes suggests that it is. Fourth, we compare the Khaling demonstrative system with that of other languages where a perceptual contrast has been reported, and show that no similar auditory demonstrative has been previously described. 


\section{Background information}

Khaling is a Sino-Tibetan language belonging to the Kiranti branch, spoken by about 15000 people in Solukhumbu district, Nepal. No reference grammar has yet been written, but a glossary (Toba and Toba 1975) and some traditional stories have been published, and a recent article describes Khaling verbal morphology Jacques et al. 2012).

\subsection{Nominalization}

The auditory demonstrative in Khaling is found in two forms: an adverbial form, tikî̀, and a nominalized form, tikî-m, which is used as a modifier. The appearance of the nominalizer $-m$ in the modifier use of tikî: fits into a wider pattern that is characteristic of Khaling and, indeed, Sino-Tibetan languages more generally.

Khaling uses the nominalizer $-m$ for a variety of functions: it is used to relativize clauses (1), to nominalize entire clauses and utterances (2), as well as to derive nominals from other lexical classes (such as adverbs and case marked elements, as in $3,4,5$ ).

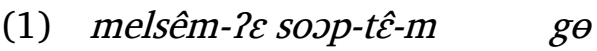

girl-ERG wash-PST-NMLZ clothes

The clothes the girl washed (elicitation)

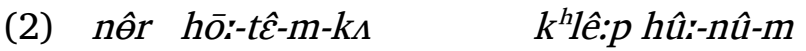

tiger come-PST-NMLZ-ABL dog bark-PL-NMLZ

Because the tiger came, the dogs bark. (meaning: it is a fact that, because the tiger came, the dogs bark; elicitation)

Example (2) shows both clause and sentence nominalization: the first clause is nominalized and then ablative-marked, in order to identify it as a reason clause. The entire sentence is also nominalized, leading to a reading as a statement of fact.

(3) phîlle-lâ-m tsû̀-ficm

Phuleli-ABL-NMLZ grandfather-PL

Those from Phuleli, the grandfathers... (Khamdime)

(4) u-k $k^{h}$ osldzosm-kolô-m $\quad g^{h}$ ruksu ge

3sG.POSS-goiter-COM-NMLZ tree.sp be:INAN

It is a tree with goitre. (said of a misshapen tree believed to have inherited the disease of the person responsible for its planting)

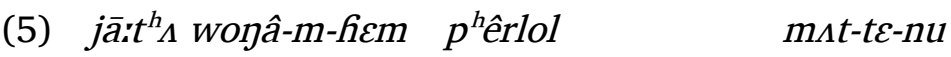

later other-NMLZ-PL younger.generation make-PST-PL

Later many others, younger generations, came to be. (Khaktsalop2) 
The association of these various functions with a single marker is a widespread phenomenon in the Sino-Tibetan languages, named Standard SinoTibetan Nominalization (SSTN) (Bickel 1999). It has been described for a number of languages of the area, among others by Matisoff (1972) for Lahu, and by Genetti et al. (2008), and more generally across Asian languages by Yap et al. (2011). The patterns found cross-linguistically are largely the same: the same marker is found with attributive/genitive marking, relativizing, and nominalizing functions, the latter applying at both the clausal and sentential levels.

\section{Auditory demonstrative}

Khaling has, as mentioned above, a demonstrative which is specifically auditory. It is used to signal that the predominant deictic feature of the referent is that it is detected through sensory input which is auditory. Consultants reject the combination of tikî-m with the noun Pu-mûr (3SG.POsssmell) 'smell' and it cannot be used to refer to taste, touch or pain.

The demonstrative adverb tikî: 'there' can be used on its own, as in example 6 , uttered by a speaker when a new radio was finally adjusted so that it was emitting sound.

(6) tikî:

there:AUD

There it is! (Heard in context)

However, it is most often used in its nominalized form tikî- $m$ as a noun modifier (7) or as a demonstrative pronoun (8).

(7) mıri mu-jed-u, tikî-m phēm mıtırbaik very NEG-like-1SG $\rightarrow$ 3SG there:AUD-NMLZ such motorbike

I really don't like motorbikes like this one. (Referring to a motorbike passing in the street making noise, invisible from the house)

(8) mân lêl tikî-m

what song there:AUD-NMLZ

What song is that? (asked by a speaker of a person listening to a song on her cell phone)

Unlike the spatial demonstratives (see section 4), the auditory demonstrative is not sensitive to relative height. For instance, sentence 9 was heard in natural conversation twice, once to refer to a sound coming from upstairs, once to refer to a sound coming from the street, two floors below the place where the conversation took place. 
(9) sît: tikî-m?

who there:AUD-NMLZ

Who is that ? (In both contexts, this sentence would correspond pragmatically to English 'Who is making that noise?')

As a modifier $t i k \hat{\imath}-m$ can be used to modify a noun with a prenominal relative clause in between (example 10).
tikî-m
kêm-go-jo
dze-pe
there:AUD-NMLZ cloud-INSIDE-LOCATIVE.LEVEL speak-NMLZ:S/A

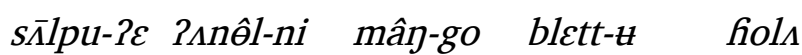
bird-ERG today-TOP what-FOC tell-3sG $\rightarrow 3$ maybe
The bird that is singing in the clouds, what might it be telling today?
(excerpt from a song by the Khaling songwriter Urmila)

In all the previous examples, tikî: and its nominalized form tikî-m were used in contexts where the referent was not visible. Unlike what it found in other languages with an auditory demonstrative, they are not used with other non-visual sensory information, such as smell and touch.

While speakers believe off-hand that the auditory demonstrative is only used for referents which are visible (see example 11, a definition provided for tikî-m by a consultant), this appears to be a case of misperception.

$$
\begin{aligned}
& \text { mu-tosç-pe, } \quad \text { ii-kî-m tîn } \\
& \text { NEG-be.visible-NMLZ:S/A hear-1PI-NMLZ:O only }
\end{aligned}
$$

Indeed, tikî: / tikî-m is routinely used for things that are visually accessible, as long as the main feature which is relevant to the context at hand is the auditory stimulus.

Examples 6 and 8 above illustrate uses of the auditory demonstratives with visible referents; likewise, 12 , uttered by a person watching a song contest on the television, makes it clear that the visibility or non-visibility of the referent is not a relevant factor in using this demonstrative.

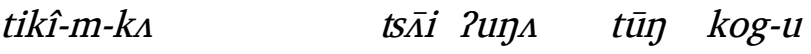

$$
\begin{aligned}
& \text { there:AUD-NMLZ-from TOP 1SG:ERG more be.able-1sG } \rightarrow \text { SSG } \\
& \text { I can (sing) better than that one. (Heard in context) }
\end{aligned}
$$

In all of the examples above, non-auditory demonstratives could also have been used. The choice of tikî-m highlights the fact that the speakers' perception is primarily via the auditory channel. 


\section{Demonstrative spatial adverbs and pronouns}

In the previous section, we showed the existence of an auditory demonstrative in Khaling. In order to provide a reliable description of the demonstrative system of this language, we must now evaluate whether a visual vs. non-visual contrast is present in the rest of the demonstrative system.

There are two systems of demonstratives in Khaling, one based on demonstrative pronouns and the other on demonstrative adverbs.

Demonstrative pronouns include the proximal $t \varepsilon$ 'this' and the distal $m \mathcal{E}$ 'that'. Like nouns and nominalized verbs or adverbs, these pronouns can receive locative case marking. The locative suffixes in Khaling present a three-way distinction between -t $t$ 'at a higher place', -jo 'away but on the same level' and $-j u$ 'at a lower place'. ${ }^{1}$ Similar systems have been documented in most Kiranti languages, such as in Belhare (Bickel 2001), Yamphu (Rutgers 1998: 96-99), Wambule (Opgenort 2004: 208-16), Hayu (Michailovsky 1988: 121).

Table 1: Demonstrative pronouns in Khaling

\begin{tabular}{lll}
\hline & proximal & distal \\
\hline base form & $t \varepsilon$ & $m \mathcal{E}$ \\
upper level & $t \mathcal{E}$ - $t \boldsymbol{t}$ 'up here' & $m \mathcal{E}$ - $t \boldsymbol{t}$ 'up there' \\
same level & $t \mathcal{E}$-jo 'here' & $m \mathcal{E}$-jo 'there' \\
lower level & $t \mathcal{\varepsilon}$-ju 'down here' & $m \mathcal{E}$-ju 'down there' \\
\hline
\end{tabular}

The 'same level' and 'lower level' demonstratives have variants exhibiting vowel fusion ( $t \mathcal{E}^{\prime}, m \bar{\varepsilon}$ ', $t \bar{i}$ : and $m \bar{i}$ ' respectively). The 'upper level' demonstratives $t \mathcal{E}$ - $t *$ 'up here' and $m \mathcal{E}$ - $t *$ 'up there' also have geminated variants $t \mathcal{E}-t t t$ and $m \mathcal{E}$ - $t t t$ indicating a greater distance from the place of reference.

These demonstratives can be further combined with other locative markers. An exhaustive description of all the possibilities is beyond the scope of this paper. ${ }^{2}$

Proximal and distal demonstrative pronouns are neutral with respect to to visibility. They can appear with visible referents as well as invisible ones as in 13 .

(13) te mân-po Pu-mûr this what-GEN 3SG.POSS-smell

\footnotetext{
${ }^{1}$ This three-way contrast closely mirrors that observed for the verbs meaning 'to come': $/ \mathrm{kho \eta} /$ 'come up from a lower place to a higher place', /pi/ 'come from a place on the same level as the point of arrival' and /je/ 'come down from a higher place to a lower place'.

${ }^{2}$ The nominalized forms can be additionally combined with the complex locative suffixes -butt 'in a higher place', -bejo 'in a place on the same level' and -buju 'in a lower place' which include the suffix $-b i$ 'in' and the three spatial suffixes $-t t$ ' on a higher place', $-j o$ 'away but on the same level' and -ju 'on a lower place' with irregular vowel harmony.
} 
What is this smell ? (elicited)

Demonstrative adverbs also distinguish three spatial levels as can been seen in Table 2. A very similar system has been described in Dumi (van Driem 1993: 81); the nominalized forms include the nominalizing suffix $-m$ along with some vowel alternations.

Table 2: Demonstrative adverbs in Khaling

\begin{tabular}{|c|c|c|c|c|}
\hline & $\begin{array}{l}\text { distal } \\
\text { adverb }\end{array}$ & nominalized & $\begin{array}{l}\text { further distal } \\
\text { adverb }\end{array}$ & nominalized \\
\hline up & tukû: & tukûm & tukkn & tukkâm \\
\hline level & jıkâ: & jıkÂm & $j \Lambda k k \Lambda$ & jıkkâm \\
\hline down & jukûu: & jukûm & jukkı & jukkâm \\
\hline
\end{tabular}

The distinction between the distal form and the further distal form (with gemination of the consonant, as the case marker -ttt above) of the adverbs in Table 2 deserves attention.

Two language consultants independently described the further distal

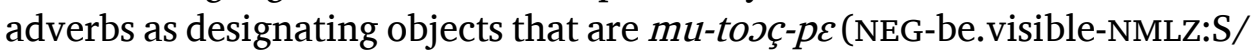
A) 'invisible', mu-the-kî-m (NEG-see-1PI-NMLZ:O) 'which we do not see' or, in sanskriticized Nepali, adrșya 'invisible'.

However, examples taken from traditional stories show that the further distal adverbs can be used even with visible objects. Example 14, from a myth about the origin of an important Khaling ritual and the danger presented by Sherpas eager to take over Khaling land, shows clearly how the further distal form, jukkı, can be used with visible objects: the adverb is combined with the verb 'to be visible'.

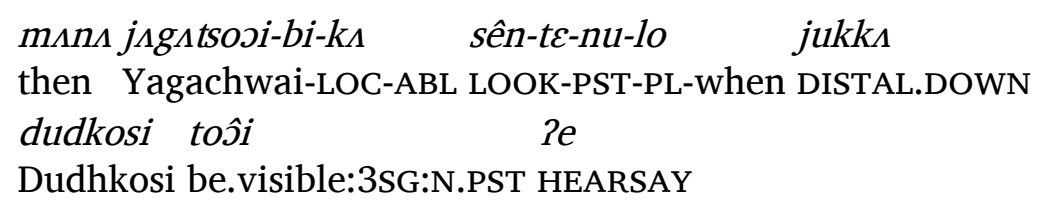

They (Sherpas) looked from Yagachwai and the DudhKosi appeared far below. (Khamdime)

Contrary to speaker perception, then, the geminated forms of the demonstrative adverbs and their nominalized forms can be used with visible objects, and the contrast is one of distance, with the geminated forms being used for further distal referents. This distal / further distal contrast is clear from example 15, where $j \Lambda k \hat{\Lambda}-m$ refers to the closer bottle while $j \Lambda k k a ̂ m$ refers to the farther one, both of them being within the field of vision. 
There is no (water) in the bottle here, but there is in the bottle over there (both bottles are visible). (elicited)

It is interesting that speakers should have intuitions about the grammaticalization of sensory contrasts which are disproven when the same speakers provide examples in spontaneous narrative. There is considerable work on the unreliability of speaker intuitions and the importance, in such a context, of corpus work (Biber 2010: 164). The data we have collected on the use of the auditory demonstrative tikî́: / tikî-m, which is interpreted by some speakers as being only applicable to invisible objects and disproven in corpus examples and elicitation, has a parallel in similar misperceptions about the incorrect non-visibility constraint for geminated forms of spatial deictics.

\section{Typological perspectives}

In reviewing demonstrative systems which encode perceptual contrasts, a number of questions must be considered:

1. Is the proximal / distal contrast in demonstratives connected to the perceptual contrasts?

2. Are there demonstratives which are exclusively visual, and which cannot be used abstractly or generically?

3. Are there demonstratives which are genuine auditory demonstratives, in other words which encode the importance to the speaker of signalling perception via an auditory channel?

It seems that cross-linguistically, systems tend to contrast visual / 'standard' demonstratives with demonstratives referring to all other senses grouped together. Sometimes, this will be described as 'auditory', because of the prevalence of the auditory channel (in information gathering) among the other senses.

Table 3 presents, for languages for which descriptions suggests the indexation of audition in the demonstrative system, the position of these languages with respect to the questions above. The data suffers from the fact that in many descriptions of languages, these distinctions are not made very 
Table 3: Systems including auditory demonstratives

\begin{tabular}{lcccl}
\hline & $\begin{array}{c}\text { Connection } \\
\text { with proximal / distal }\end{array}$ & $\begin{array}{c}\text { Indexation of } \\
\text { visual perception }\end{array}$ & $\begin{array}{c}\text { Indexation of distinctions } \\
\text { between audition and other senses }\end{array}$ & References \\
\hline Santali & no & yes & no & Neukom (2001: 42-44) \\
Nyelayu & yes & yes & no & Ozanne-Rivierre (1997: 98) \\
Southern Pomo & unknown & unclear & no & Oswalt (1986: 37, ft) \\
Muna & yes & yes & no & van den Berg (1997) \\
Dyirbal & yes & yes & no & Dixon (1972) \\
\hline Khaling & no & no & yes & \\
\hline
\end{tabular}

clearly. What can be said from our examination of data currently available is that Khaling stands out among other languages in being the only one to have a genuine auditory demonstrative.

None of the languages in Table 3 presents the same exact system.

In Santali (Neukom 2001: 42-44), we find a contrast between standard, visual and 'auditive' demonstratives (in addition to number and proximal/ distal distinctions). The 'auditive' demonstrative is best characterized as non-visual sensory; according to Neukom (2001: 42) it can be used to refer to smell, taste, and touch.

In Dyirbal, Muna, and Nyelayu, the sensory distinction in demonstratives is not clearly separate from the proximal / distal distinction. In Dyirbal and Muna, there are demonstratives that can be used to refer to invisible but audible objects, but audibility is not described as an essential feature.

Nyelayu (Ozanne-Rivierre 1997: 98) presents a system with four degrees depending on the proximity of the referent to the speaker: near the speaker, distant but visible, distant and invisible but audible and absent but known to the speakers. It is thus a system with a tripartite sensory distinction (visible; invisible but audible ; neither visible nor audible).

Unpublished work by Bril 2013 describes a similar phenomenon in the related language Yuanga. In that language the demonstrative -ili cognate with the one described as referring 'invisible but audible' objects in Nyelayu is also non-visual, but can be used to indicate perception through taste and other senses.

In the Mihilakawna dialect of Southern Pomo, Oswalt (1986: 37, ft) suggests the existence of an audible demonstratives, without providing a detailed description, and without clear mention of the presence or absence of visual demonstratives, as the information is in a footnote in an article on a different language. The most recent grammar of Southern Pomo does not mention the existence of such phenomena (Walker 2013: 232).

Precise information on the use of the auditory demonstrative is lacking for Nyelayu and Southern Pomo, so that it is difficult to assess whether it can be used with senses other than hearing; from the available descriptions it is also tricky to determine to what extent the auditory demonstratives are exclusively used with invisible referents. As we have shown in the case of Khaling, the intuitions of native speakers can be misleading if not rechecked 
against the actual use of these words in context.

Khaling is thus the only language for which positive evidence shows the presence of a genuine auditory demonstrative, as opposed to a non-visual sensory one.

\section{Conclusion}

This paper describes the auditory demonstrative in Khaling, which represents, as far as we are able to ascertain, a novel configuration among attested demonstrative systems.

We have shown that Khaling, unlike other systems described heretofore, has a genuine auditory demonstrative: in its adverbial or nominalized form, tikî: / tikî-m is used to signal that the relevant perceptive channel in identifying the referent is audition rather than vision. The auditory demonstrative is not associated with a distal / proximal contrast and the demonstrative system does not highlight other senses: Khaling's demonstrative pronouns (Table 1) and adverbs (Table 2) do not encode visibility, and the auditory demonstrative is used to signal perception via audition and not via any other sense, although it can be used when other sensory input is present in addition to audition.

We feel that the nature of the auditory demonstrative in Khaling is unique with respect to currently-available descriptions of demonstrative systems, and hope that this contribution may spur investigations into similar perceptual phenomena in demonstrative systems of other languages.

\section{References}

Aikhenvald, Alexandra. 2004. Evidentiality. Oxford: Oxford University Press.

Aikhenvald, Alexandra, and R.M.W. Dixon. 2014. The grammar of knowledge: a cross-linguistic view of evidentials, and the expression of information source. Oxford: Oxford University Press.

van den Berg, René. 1997. Spatial deixis in Muna (Sulawesi). In Referring to Space: Studies in Austronesian and Papuan Languages, ed. G. Senft: 197220. Oxford: Oxford University Press.

Biber, Douglas. 2010. Corpus-based and corpus-driven analyses. In The Oxford Handbook of Linguistic Analysis, ed. Berndt Heine and Heiko Narrog: 159-192. Oxford: Oxford University Press. 
Bickel, Balthasar. 1999. Nominalization and focus constructions in some Kiranti languages. In Topics in Nepalese Linguistics, ed. Yogendra P. Yadava and Warren G. Glover: 271 - 296. Kathmandu: Royal Nepal Academy.

Bickel, Balthasar. 2001. Deictic Transposition and Referential Practice in Belhare. Journal of Linguistic Anthropology 10.2:224-247.

Boas, Franz. 1911. Kwakiutl. In Handbook of American Indian Languages. Part 1, ed. Franz Boas: Bureau of American Ethnology Bulletin 40: 423557. Smithsonian Institution.

Bril, Isabelle. 2013. Unpublished fieldwork notes on Yuanga.

Diessel, Holger. 1999. Demonstratives: Form, Function, and Grammaticalization. Amsterdam: Benjamins.

Dixon, Robert M. W. 1972. The Dyirbal Language of North Queensland. Cambridge: Cambridge University Press.

van Driem, George. 1993. A Grammar of Dumi. Berlin: Mouton de Gruyter.

Genetti, Carol, Ellen Bartee, Alec Coupe, Kristine Hildebrandt, and Youjing Lin. 2008. Syntactic aspects of nominalization in five Tibeto-Burman languages of the Himalayan area. Linguistics of the Tibeto-Burman Area 31.2:97-144.

Jacques, Guillaume, Aimée Lahaussois, Boyd Michailovsky, and Dhan Bahadur Rai. 2012. An overview of Khaling verbal morphology. Language and linguistics 13.6:1095-1170.

Matisoff, James. 1972. Lahu nominalization, relativization, and genetivization. In Syntax and semantics, Vol 1, ed. John Kimball: 237-257. New York: Academic Press.

Michailovsky, Boyd. 1988. La langue hayu. Paris : Editions du CNRS.

Neukom, Lukas. 2001. Santali. München: Lincom Europa.

Opgenort, Jean-Robert. 2004. A Grammar of Wambule. Leiden: Brill.

Oswalt, Robert L. 1986. The evidential system of Kashaya. In Evidentiality: The Linguistic Coding of Epistemology, ed. Wallace L. Chafe and Johanna Nichols: 29-45. Norwood, NJ:Ablex.

Ozanne-Rivierre, Françoise. 1997. Spatial references in New Caledonian languages. In Referring to Space. Studies in Austronesian and Papuan Languages, ed. Gunter Senft. Oxford: Clarendon Press.

Rutgers, Roland. 1998. Yamphu, Grammars, Texts and Lexicon. Leiden: Research School CNWS. 
Toba, Sueyoshi, and Ingrid Toba. 1975. A Khaling-English, English-Khaling Glossary. Kathmandu: Summer Institute of Linguistics.

Walker, Neil Alexander. 2013. A Grammar of Southern Pomo, An Indigenous Language of California. Doctoral Dissertation: University of California, Santa Barbara.

Yap, F-H., K. Grunow-Hårsta, and J. Wrona. 2011. Nominalization in Asian Languages. Amsterdam: Benjamins. 